\title{
Akta Sebagai Produk Akhir Notaris Menjadi Objek Dalam Persidangan Pidana Pada Pengadilan Negeri Sleman
}

\section{Elsi Vita Sari}

Magister Kenotariatan Fakultas Hukum Universitas Islam Indonesia Yogyakarta Indonesia Jln. Cik Di Tiro No. 1 Yogyakarta Indonesia vitaelsy@gmail.com

\begin{tabular}{ll}
\hline Key Word: & Abstract \\
Deed; & notary; \\
hearing & This study examines "Deed as the Notary's Final Product Subjected to a Criminal \\
& Trial at the Sleman District Court". The problems formulation are first, whether the \\
& final product of a Notary in the form of a deed can be questioned criminally, and \\
& second, how is the judge's consideration of a pure acquittal against a Notary who \\
& made the deed that is questioned in the criminal trial at the Sleman District Court. \\
& This type of research is normative juridical which is supported by information from \\
& sources. The approach used in this research is a statutory, sociological and case \\
& approach. The results of this study conclude that, first, the final product of a Notary \\
& in the form of a deed can be questioned criminally if the criminal elements in the \\
& making of the deed can be proven, (i) a deed made before a Notary (consensus) is \\
& used as the basis for committing a crime, (ii) a Notary in the making of the deed \\
& before or by a Notary which if measured based on the UuJN is not in accordance \\
& with the UUJN and (iii) the actions of the Notary are not in accordance with their \\
& authorities. Second, the judge's consideration of the pure acquittal of a notary who \\
& made the deed was questioned in the criminal trial at the Sleman District Court \\
& because the public prosecutor could not prove the existence of a debt agreement, and \\
the criminal elements charged by the public prosecutor were "fraud committed \\
collectively" was not proven at trial
\end{tabular}

Kata-kata Kunci:
Akta; persidangan;
notaris

Abstrak

Penelitian ini meneliti tentang "Akta Sebagai Produk Akhir Notaris Yang Menjadi Objek Persidangan Pidana Pada Pengadilan Negeri Sleman". Masalah yang dirumuskan pertama, apakah produk akhir Notaris berupa akta dapat dipersoalkan secara pidana, dan kedua, bagaimana pertimbangan Hakim atas putusan bebas murni terhadap seorang Notaris yang membuat akta dipersoalkan dalam persidangan pidana pada Pengadilan Negeri Sleman tersebut. Jenis penelitian ini adalah yuridis normatif yang didukung dengan keterangan narasumber. Pendekatan yang dilakukan dalam penelitian ini adalah pendekatan perundang-undangan dan pendekatan kasus. Hasil penelitian ini menyimpulkan, pertama, produk akhir Notaris berupa akta dapat dipersoalkan secara pidana apabila unsur-unsur pidana dalam pembuatan akta dapat dibuktikan, (i) akta yang dibuat dihadapan Notaris (sepakat) dijadikan dasar melakukan suatu tindak pidana, (ii) Notaris dalam membuat akta di hadapan atau oleh Notaris yang jika diukur berdasarkan UUJN tidak sesuai dengan UUJN dan (iii) tindakan Notaris tersebut tidak sesuai menurut instansi yang berwenang. Kedua, pertimbangan Hakim atas putusan bebas murni terhadap seorang Notaris yang membuat akta dipersoalkan dalam persidangan pidana pada Pengadilan Negeri Sleman tersebut karena Penuntut Umum tidak dapat membuktikan adanya perjanjian hutang piutang, dan unsur-unsur pidana yang didakwakan oleh Penuntut Umum yaitu "penipuan yang di lakukan secara bersama-sama" tidak terbukti pada persidangan. 


\section{Pendahuluan}

Notaris saat ini berperan mendukung dan mendorong berbagai kegiatan di bidang hukum, khususnya kenotariatan yang sangat berperan dalam memberikan pelayanan hukum kepada masyarakat. Sebagaimana disebutkan dalam Pasal 1 ayat (1) UndangUndang Nomor 2 Tahun 2014, terkait dengan perubahan atas Undang-Undang Nomor 30 Tahun 2004 Tentang Jabatan Notaris (UUJN), yang mengatur bahwa notaris adalah pejabat umum yang memiliki wewenang untuk membuat akta otentik dan memiliki kewenangan lainnya sebagaimana dimaksud dalam Undang-undang ini atau berdasarkan Undang-undang lainnya. Lembaga notariat dikenal sebagai suatu lembaga dalam masyarakat yang muncul karena adanya kebutuhan dalam masyarakat itu sendiri yang menghendaki adanya alat bukti hukum bagi mereka yang membutuhkan. ${ }^{1}$ Notaris berwenang dalam membuat akta otentik mengenai semua perbuatan, perjanjian dan ketetapan yang diharuskan oleh peraturan perundang-undangan. ${ }^{2}$

Notaris dalam membuat akta tentunya bersinggungan dengan hukum pidana, dan dalam prakteknya, ada oknum-oknum yang menyalahgunakan. Maka dari itu Notaris harus selalu berhati-hati dalam menjalakan tugas dan jabatannya. Contoh kasus yang terjadi di Kabupaten Sleman pada putusan Pengadilan Negeri Sleman Nomor: 63/Pid.B/2020/PNSmn yang melibatkan seorang Notaris bersama-sama dengan saksi B. Terdakwa dituntut pidana oleh Penuntut Umum melakukan tindak pidana "Penipuan yang dilakukan secara bersama sama" sebagaimana diatur dan diancam Pidana dalam Pasal 378 jo. Pasal 55 ayat (1) ke 1 Kitab Undang-Undang Hukum Pidana ${ }^{3}$. Perbuatan tersebut dilakukan oleh Terdakwa Notaris tersebut bersama-sama dengan saksi B yaitu berawal dari adanya kesepakatan antara saksi B dan saksi A terhadap penyelesaian kredit macet di salah satu Bank di Kota Yogyakarta. Saksi B meminjamkan uang dengan jaminan 11 Sertifikat Hak Milik kepada Saksi A. Kemudian saksi B datang menghadap kepada Notaris dengan niat untuk membuat perjanjian hutang piutang tetapi seolah-olah telah terjadi jual beli dengan dibuatkan perikatan jual belinya dan Notaris tersebut menyanggupinya. Selanjutnya Notaris membuat surat tugas yang isinya menugaskan stafnya guna mengambil 11 sertrifikat yang menjadi jaminan di salah satu Bank. Setelah itu, saksi B mengirimkan uang kepada Notaris untuk pengajuan pengurusan pengajuan izin pemanfaatan tanah (IPT) karena terdapat obyek 2 bidang tanah sawah sedangkan pada saat itu belum terjadi penandatangan perikatan jual beli antara saksi B dengan saksi A. Terdakwa didakwa mempunyai niat jahat untuk membuat akta-akta yang klausulnya tidak sesuai dengan peristiwa hukum yang sebenarnya terjadi dengan cara mempersiapkan data-data administrasi dan perkataan bohong melakukan tipu muslihat membujuk saksi A untuk merubah kesepakatan hutang piutang menjadi perjanjian jual beli sehingga merugikan saksi A.

Menurut pertimbangan Majelis Hakim Pengadilan Negeri Sleman dalam putusannya menyatakan menolak seluruh dakwaan Penuntut Umum karena tidak dapat

1 Abintoro Prakoso, Etika Profesi Hukum, LaksBang Justitia, 2015, hlm. 135.

${ }^{2}$ Habib Adjie, Hukum Notaris Indonesia, PT. Refika Aditama, Bandung, 2008, hlm. 8.

3 Putusan Pengadilan Negeri Sleman Nomor: 63/Pid.B/2020/PNSmn, diakses 1 Desember 2020, Pukul 10.00 WIB. 
membuktikan dakwaannya dan memutuskan Notaris tersebut bebas murni, tidak terbukti bersalah, serta dipulihkan hak-hak Terdakwa dalam kemampuan, kedudukan, harkat serta martabatnya. Pertimbangan Hakim memutuskan bebas murni yaitu karena berdasarkan fakta-fakta yang terungkap dalam persidangan bahwa benar telah terjadi jual beli antara saksi B dan saksi A bukan hutang piutang, kemudian seluruh akta yang ditandatangani di hadapan Terdakwa adalah benar dan autentik. Penuntut Umum juga tidak dapat membuktikan adanya perjanjian hutang. ${ }^{4}$

\section{Rumusan Masalah}

Berangkat dari latar belakang masalah sebagaimana telah diuraikan diatas, maka fokus penelitian ini hanya akan merujuk pada 2 persoalan utama yang akan dianalisis adalah pertama, apakah produk akhir Notaris berupa akta dapat dipersoalkan secara pidana? Kedua, bagaimana pertimbangan Hakim atas putusan bebas murni terhadap seorang Notaris yang membuat akta dipersoalkan dalam persidangan pidana pada Pengadilan Negeri Sleman tersebut?

\section{Tujuan Penelitian}

Penelitian ini bertujuan untuk: pertama, menganalisis dan mengkaji produk akhir Notaris berupa akta dapat dipersoalkan secara pidana dan menganalisis. Kedua, mengkaji tentang pertimbangan Hakim atas putusan bebas murni terhadap seorang Notaris yang membuat akta dipersoalkan dalam persidangan pidana Pengadilan Negeri Sleman tersebut.

\section{Metode Penelitian}

Pada penulisan penelitian ini, penulis menggunakan jenis penelitian yuridis normatif yang didukung dengan keterangan narasumber dan menggunakan pendekatan perundang-undangan dan kasus. Data penelitian dalam penyusunan ini bersumber dari data primer dan data sekunder. Data primer yakni merupakan data yang diperoleh atau dikumpulkan langsung dari narasumber, yang diperoleh berdasarkan hasil wawancara. Untuk data sekunder diperoleh dari bahan pustaka. ${ }^{5}$ Data sekunder dibagi atas bahan hukum primer berupa peraturan perundang-undangan, bahan hukum sekunder berupa buku-buku Ilmu Hukum, dan bahan hukum tersier berupa kamus. Teknik pengumpulan data yang digunakan dalam penelitian ini adalah studi dokumen/kepustakaan dan wawancara. Metode yang digunakan dalam menganalisa data adalah deskriptif kualitatif, yaitu mengemukakan data dan informasi tersebut kemudian dianalisis dengan memakai beberapa kesimpulan sebagai temuan dari hasil penelitian.

${ }_{4}$ Putusan Pengadilan Negeri Sleman Nomor: 63/Pid.B/2020/PNSmn, diakses 1 Desember 2020, Pukul 10.00 WIB.

${ }^{5}$ M. Syamsudin, Operasionalisasi Penelitian Hukum, P'T. Raja Grafindo Persada, Jakarta, 2007, hlm. 89. 


\section{Hasil Penelitian dan Pembahasan}

\section{Produk Akhir Notaris Berupa Akta Dipersoalkan Secara Pidana}

Apabila seorang Notaris membuat atau berkerjasama dan menandatangani suatu akta, palsu atau akta pura-pura. Maka terhadap Notaris terebut dapat dikenakan pidana penyertaan pemalsuan akta sebagaimana diatur dalam Pasal 55 ayat (1) angka 1 jo. Pasal 263 ayat (1) KUHP. Pengkualifikasian tersebut berkaitan dengan aspek-aspek seperti:

1. Kepastian hari, tanggal, bulan, tahun dan pukul menghadap;

2. Pihak (siapa orang) yang menghadap Notaris;

3. Tanda tangan yang menghadap;

4. Salinan akta tidak sesuai dengan minuta akta;

5. Salinan akta ada, tanpa dibuat minuta akta dan;

6. Minuta akta tidak ditanda tangani secara lengkap tapi minuta akta dikeluarkan.

Aspek-aspek tersebut jika terbukti dilanggar oleh Notaris, maka Notaris yang bersangkutan dapat dijatuhi sanksi perdata atau administrasif atau aspek-aspek tersebut merupakan batasan-batasan apabila dapat dibuktikan dapat dijadikan dasar untuk menjatuhkan sanksi administratif dan sanksi perdata terhadap Notaris. Namun ternyata dari sisi yang lain batasan-batasan seperti itu ditempuh atau diselesaikan secara pidana atau dijadikan dasar untuk mempidanakan Notaris dengan dasar bahwa Notaris telah membuat surat palsu atau memalsukan akta dengan kualifikasi sebagai suatu tindak pidana yang dilakukan oleh Notaris.

Produk akhir Notaris dapat dipersoalkan secara pidana apabila unsur-unsur pidana dalam pembuatan akta dapat dibuktikan. Unsur-unsur pidana tersebut adalah sebagai berikut:

1. Ada tindakan hukum dari Notaris terhadap aspek formal yang sengaja, penuh kesadaran dan keinsyafan serta direncanakan, bahwa akta yang dibuat dihadapan Notaris atau Notaris bersama-sama (sepakat) untuk dijadikan dasar untuk melakukan suatu tindak pidana;

2. Ada tindakan hukum dari Notaris dalam membuat akta di hadapan atau oleh Notaris yang jika diukur berdasarkan UUJN tidak sesuai dengan UUJN dan;

3. Tindakan Notaris tersebut tidak sesuai menurut instansi yang berwenang untuk menilai tindakan Notaris dalam hal Majelis Pengawas Notaris. ${ }^{6}$

Dalam kasus yang penulis teliti, unsur-unsur pidana yang dipaparkan di atas tidak terbukti pada kasus salah satu Notaris di Kabupaten Sleman tersebut, sehingga produk akhir Notaris yang dikeluarkan oleh Terdakwa selaku Notaris tidak dapat dipersoalkan secara pidana. Hakim Pengadilan Negeri Sleman memutuskan Terdakwa yaitu bebas murni. Putusan Hakim memutuskan Terdakwa selaku Notaris bebas murni adalah keputusan yang tepat.

Menurut penulis, produk akhir Notaris yang dikeluarkan oleh Terdakwa selaku Notaris tidak dapat dipersoalkan secara pidana karena tidak memenuhi unsur-unsur pidana. Hal ini dapat dibuktikan dengan tidak adanya dan tidak terbukti bahwa telah

${ }^{6}$ Habib Adjie, Sanksi Perdata dan Administratif Terbadap Notaris Sebagai Pejabat Publik, PT Refika Aditama, Bandung, 2009, hlm. 125 
ada tindakan hukum yang disengaja terhadap aspek formal oleh Terdakwa selaku Notaris penuh kesadaran dan keisyafan serta direncanakan, kemudian akta-akta yang dikeluarkan oleh Terdakwa selaku Notaris apabila diukur berdasarkan UUJN sudah sesuai dan tidak ada pelanggaran terhadap UUJN dan sudah diputuskan oleh Hakim Pengadilan Negeri Sleman bahwa akta-akta yang dibuat oleh Terdakwa selaku Notaris adalah benar dan otentik. Akta-akta yang dikeluarkan oleh Terdakwa selaku Notaris sudah memnuhi syarat dan bentuk yang telah ditetapkan oleh UUJN. Apabila dihubungkan dengan Pasal 38 UUJN maka disebutkan bahwa akta Notaris dapat dikatakan memenuhi syarat apabila akta-akta yang dibuat atau dihadapan Notaris telah sesuai dengan bentuk yang telah ditetapkan.

\section{Pertimbangan Hakim atas Putusan Bebas Murni terhadap Seorang Notaris yang Membuat Akta Dipersoalkan dalam Persidangan Pidana Pada Pengadilan Negeri Sleman}

Pertimbangan Hakim atas putusan bebas terhadap seorang Notaris yang membuat akta dipersoalkan dalam persidangan pidana pada Pengadilan Negeri Sleman tersebut adalah bahwa Penuntut Umum tidak dapat membuktikan adanya perjanjian hutang piutang, kemudian benar telah terjadi jual beli antara saksi A dan saksi B bukan hutang piutang, bahwa keseluruhan akta-akta yang dibuat oleh Terdakwa adalah benar dan otentik.

Menurut penulis, pertimbangan Hakim memutuskan bebas murni terhadap seorang Notaris di Pengadilan Negeri Sleman tersebut adalah keputusan yang sudah tepat. Unsur-unsur pidana yang didakwakan pada Terdakwa selaku Notaris yaitu "penipuan yang dilakukan secara bersama-sama" Pasal 378 KUHP jo. Pasal 55 ayat (1) ke 1 KUHP yaitu (1) bermaksud untuk menguntungkan diri sendiri atau orang lain secara melawan hukum, (2) "Menghendaki" atau setidaknya "mengetahui atau menyadari" bahwa perbuatannya sejak semula memang ditujukan untuk menggerakkan orang lain agar orang lain tersebut menyerahkan suatu benda/memberi hutang/menghapuskan piutang kepadanya (pelaku delik), (3) "Mengetahui/menyadari" bahwa yang ia pergunakan untuk menggerakkan orang lain, sehingga menyerahkan suatu benda/memberi hutang/menghapuskan piutang kepadanya itu adalah dengan memakai nama palsu, martabat palsu atau sifat palsu, tipu muslihat atau rangkaian kebohongan.

Unsur-unsur pidana yang didakwakan oleh Penuntut Umum terhadap Terdakwa selaku Notaris adalah tidak terbukti sehingga sudah sepatutnya Hakim memutuskan bebas murni. Terungkap fakta-fakta dalam persidangan bahwa tidak ada kejadian dan perbuatan yang dilakukan oleh Terdakwa sebagai Notaris yang melanggar Undangundang. Adapun fakta-fakta yang terungkap dalam persidangan adalah bahwa Penuntut umum tidak dapat membuktikan adanya perjanjian hutang piutang dan tidak secara komprehensif mempertimbangkan keterkaitan saksi-saksi dan alat-alat bukti yang diajukan dipersidangan, dan benar telah terjadi jual beli antara saksi A dan saksi B dan bukan perjanjian hutang piutang seperti yang dimaksud dalam dakwaan, kemudian bahwa benar keseluruhan akta-akta yang dibuat oleh Terdakwa selaku Notaris adalah benar dan otentik. 


\section{Penutup}

\section{Kesimpulan}

Bedasarkan kajian di atas disimpulkan, pertama, produk akhir Notaris dapat dipersoalkan secara pidana apabila unsur-unsur pidana dalam pembuatan akta dapat dibuktikan. Unsur-unsur pidana tersebut adalah (1) ada tindakan hukum dari Notaris terhadap aspek formal yang sengaja, penuh kesadaran serta direncanakan, bahwa akta yang dibuat dihadapan Notaris atau Notaris bersama-sama (sepakat) untuk dijadikan dasar untuk melakukan suatu tindak pidana, (2) Notaris dalam membuat akta di hadapan atau oleh Notaris yang jika diukur berdasarkan UUJN tidak sesuai dengan UUJN dan, (3) tindakan Notaris tersebut tidak sesuai menurut instansi yang berwenang untuk menilai tindakan Notaris dalam hal Majelis Pengawas Notaris. Dalam kasus yang penulis teliti, unsur-unsur pidana yang dipaparkan di atas tidak terbukti pada kasus salah satu Notaris di Kabupaten Sleman tersebut, sehingga produk akhir Notaris yang dikeluarkan oleh Terdakwa selaku Notaris tidak dapat dipersoalkan secara pidana.

Kedua, pertimbangan Hakim atas putusan bebas terhadap seorang Notaris yang membuat akta dipersoalkan dalam persidangan pidana pada Pengadilan Negeri Sleman tersebut adalah bahwa Penuntut Umum tidak dapat membuktikan adanya perjanjian hutang piutang, kemudian benar telah terjadi jual beli antara saksi A dan saksi B bukan hutang piutang, bahwa keseluruhan akta-akta yang dibuat oleh Terdakwa adalah benar dan otentik. Menurut penulis, pertimbangan Hakim memutuskan bebas murni adalah keputusan yang sudah tepat. Unsur-unsur pidana yang didakwakan pada Terdakwa selaku Notaris yaitu "penipuan yang dilakukan secara bersama-sama" Pasal 378 KUHP jo. Pasal 55 ayat (1) ke 1 KUHP yaitu (a) bermaksud untuk menguntungkan diri sendiri atau orang lain secara melawan hukum, (b) "Mengetahui atau menyadari" bahwa perbuatannya sejak semula memang ditujukan untuk menggerakkan orang lain agar menyerahkan suatu benda/memberi hutang/menghapuskan piutang kepadanya (c) "Mengetahui/menyadari" bahwa yang ia pergunakan untuk menggerakkan orang lain, sehingga menyerahkan suatu benda/memberi hutang/menghapuskan piutang kepadanya itu adalah dengan memakai nama palsu, martabat palsu atau sifat palsu, tipu muslihat atau rangkaian kebohongan. Unsur-unsur pidana yang didakwakan oleh Penuntut Umum terhadap Terdakwa selaku Notaris adalah tidak terbukti sehingga sudah sepatutnya Hakim memutuskan bebas murni.

\section{Saran}

Pertama, Notaris dalam membuat akta agar terhindar dari ancaman pidana maka sebaiknya untuk selalu bertindak cermat, hati-hati dan belajar meningkatkan kemampuan untuk mendalami mengenai peraturan perundang-undangan yang berlaku dengan baik selama menjalankan jabatan sebagai Notaris.

Kedua, notaris harus dapat menganalisis keinginan dari para pihak Notaris harus teliti dan preventif di segala hal, baik itu preventif dokumen misal ada kecurigaan maka sebaiknya ditanyakan secara halus kepada para pihak karena apabila sudah dibuktikan bahwa Notaris sudah teliti dan preventif tetapi para pihak tetap melakukan 
penyelubungan, maka letak tanggung jawab dari isi akta tersebut terdapat pada para pihak tersebut, bukan pada Notaris.

\section{Daftar Pustaka}

\section{Buku}

Arikunto, Suharsimi, Prosedur Penelitian Suatu Pendekatan Praktik, Rineka Cipta, Jakarta, 2011.

Habib, Adjie, Hukum Notaris Indonesia, PT. Refika Aditama, Bandung, 2008.

Sanksi Perdata dan Administratif terhadap Notaris sebagai Pejabat Publik, Refika Aditama, Bandung, 2009.

Prakoso, Abintoro, Etika Profesi Hukum, LaksBang Justitia, Jakarta, 2015.

Syamsudin, M., Operasionalisasi Penelitian Hukum, PT. Raja Grafindo Persada, Jakarta, 2007.

\section{Perundang-undangan}

Kitab Undang-Undang Hukum Perdata

Kitab Undang-Undang Hukum Pidana

Peraturan Menteri Hukum dan Hak Asasi Manusia Republik Indonesia Nomor 7 Tahun 2016 tentang Majelis Kehormatan Notaris.

Undang-Undang Nomor 2 Tahun 2014 tentang Perubahan Atas Undang-Undang Nomor 30 Tahun 2004 tentang Jabatan Notaris 